\title{
SISTEM WAKAF DI NEGARA LEBANON: Undang-undang Perwakafan dalam Heterogenitas Agama
}

\author{
Oleh : \\ Vita Fitria \\ MKU Universitas Negeri Yogyakarta \\ vitafitria08@gmail.com
}

\begin{abstract}
Abstrak
Persoalan wakaf dalam Islam semakin mempunyai wilayah yang lebih kompleks baik dalam penerapan, persyaratan maupun pengelolaan. Beberapa negara Muslim mulai membentuk satu Undang-undang atau lembaga tersendiri yang khusus mengatur masalah perwakafan. Lembaga ini berfungsi untuk mengoptimalkan operasionalisasi perwakafan berikut administrasinya, agar terhindar dari penyimpangan dan kesimpangsiuran terutama dengan pihak ahli waris atau keturunan dari si pemberi wakaf . Lebanon merupakan salah satu negara Muslim yang mempunyai heterogenitas keagamaan. Meskipun Islam sebagai agama mayoritas, ada agama-agama lain yang mempunyai otoritas hukum yang sama. Dalam menyelesaikan masalah wakaf, masyarakat Muslim Lebanon sudah mempunyai Undang-undang sendiri yaitu Undang-undang Wakaf Keluarga tahun 1947 yang diadopsi dari Undang-undang Wakaf Mesir tahun 1946. Tulisan ini akan memaparkan tentang sistematika hukum perwakafan bagi masyarakat Muslim di Lebanon, berikut catatan dinamika penerapannya sistem wakaf bagi komunitas Druze ( sekte keagamaan yang berkembang di Lebanon) sebagai pembanding.
\end{abstract}

Kata Kunci : Sistem Perwakafan, Lebanon, Undang- Undang Wakaf.

\section{Pendahuluan}

Wakaf dalam bahasa Arab berasal dari kata kerja waqafa-yaqifu-waqfan, yang berarti berhenti atau berdiri (AshShan'aniy, t.t: 114). Secara harfiah bermakna "pembatasan" atau "larangan",dengan maksud, pemilikan atau pemeliharaan harta benda tertentu untuk kemanfaatan sosial tertentu yang ditetapkan dengan maksud mencegah penggunaan harta tersebut di luar tujuan khusus yang telah ditetapkan (Esposito, 2001: 145).

Bentuk-bentuk wakaf yang pernah ada pada jaman nabi antara lain berupa, masjid yang tanah maupun bangunannya secara eksklusif menyediakan penghasilan untuk pemeliharaan dan pendanaannya. Masjid tersebut adalah masjid Quba dan masjid Nabawi di Madinah. Ada juga dalam bentuk derma (filantropis) yang ditujukan untuk menyantuni kaum fakir miskin atau kepentingan umum secara luas, misalnya dalam bentuk pendidikan, perpustakaan/ buku-buku, pelayanan kesehatan, atau dalam bidang pembangunan misalnya pemeliharaan taman, jalan raya, 
jembatan, bendungan dan sebagainya. Ada juga yang berupa wakaf keluarga, seperti yang terjadi pada masa khalifah Umar bin Khattab.

Wakaf mempunyai sifat kekal, dalam arti, begitu sebuah harta diwakafkan, selamanya barang tersebut menjadi harta wakaf yang tidak bisa diperjualbelikan. Dalam konteks ini, wakaf berbeda dengan yayasan sebab managemen yayasan lazimnya dapat menjual hartanya (Esposito, 2001: 146). Pada prinsipnya pembuat wakaf menentukan bentuk pengelolaan wakafnya sendiri. Pengelola tersebut (yang biasa disebut mutawalli atau nadzir) bertugas mengelola dan mengatur harta wakaf sebaik-baiknya untuk kepentingan penerima wakaf. Bila terjadi sengketa, maka pengadilan memiliki wewenang untuk menyelesaikan.

Mundurnya peradaban dunia Islam, turut mempengaruhi kemerosotan moral kaum muslim. Adanya korupsi sampai tingkat wakaf, mengundang pemerintah untuk turut mencampuri perselisihan problem perwakafan. Sebagai contoh pada awal abad 19, pemerintah Turki Utsmani membentuk kabinet khusus yang menangani soal wakaf. Yaitu Undang-undang yang dikeluarkan pada tanggal 29 November 1863 yang berfungsi mengatur pengelolaan dan pengawasan wakaf (Esposito, 2001: 148).

Sejalan dengan perkembangan zaman, persoalan wakaf terutama dalam Islam semakin mempunyai wilayah yang lebih kompleks baik dalam penerapan, persyaratan maupun pengelolaan. Pada akhirnya tidak bisa diabaikan begitu saja, beberapa negara Muslim mulai membentuk satu Undang-undang atau lembaga tersendiri yang khusus mengatur masalah perwakafan. Lembaga ini berfungsi untuk mengoptimalkan operasionalisasi perwakafan berikut administrasinya, agar terhindar dari penyimpangan dan kesimpangsiuran terutama dengan pihak ahli waris atau keturunan dari si pemberi wakaf (Anderson, 1976: 162). Wakaf sendiri bisa dikatakan terbagi dalam dua katagori, yakni wakaf khairi (wakaf komunal), yang tujuannya adalah untuk kepentingan umum, dan wakaf ahli (wakaf keluarga) yang ditujukan untuk keluarga-keluarga tertentu atau ahli warisnya.

Dalam lembaga Peradilan Islam, yang mempunyai wewenang menangani dan mengelola masalah perwakafan adalah mutawalli atau nadzir. Namun ada beberapa Negara Muslim yang mempunyai kementrian atau lembaga khusus yang menangani masalah wakaf dan mempunyai wewenang secara legal. 
Salah satunya di Negara Lebanon. Dengan diundangkannya Undangundang Wakaf Keluarga tahun 1947 yang diadopsi dari Undang-undang Wakaf Mesir tahun 1946, maka masalah perwakafan di Lebanon, terutama wakaf keluarga, mulai terorganisir sesuai ketentuan-ketentuan hukum yang berlaku.

Selanjutnya, meski dengan keterbatasan data, makalah ini mencoba untuk mengulas sistem wakaf di negara tersebut. Karena masing-masing sekte keagamaan mempunyai sistem hukum sendiri dan diakui oleh negara, maka sebagai perbandingan, penulis juga akan sedikit mengulas sistem wakaf yang terjadi di kalangan komunitas Druze di Lebanon.

Sebelumnya, akan penulis diskripsikan dahulu perihal negara Lebanon, baik secara politik, komunitas penduduknya, perkembangan agama, maupun perkembangan sistem hukum keluarga yang berlaku.

\section{Gambaran Umum Negara Lebanon}

\section{a. Gambaran Umum}

Lebanon adalah negara kecil yang terletak di tepi Laut Tengah di Asia Barat Daya. Sebelah timur berbatasan dengan Syiria, Selatan dengan Israel dan sebelah Barat dengan Laut Mediterania (Lexicon, tt). Lebanon, atau dalam bahasa Arab disebut Lubnan, disamping merupakan komunitas Islam dalam wilayah Arab yang berperadaban Islam, juga termasuk satu komunitas dunia Kristen yang berbahasa Perancis (Lewis, Pellat, Schacht, 1986: 787). Berdasarkan data sampai tahun 2014, Negara Lebanon mempunyai luas wilayah sekitar 4.035 square miles (atau sekitar $10.452 \mathrm{~km} 2$ ) dengan jumlah penduduk sekitar 4,46 juta jiwa saja. (https://id.wikipedia.org/wiki/Lebanon\#). Beirut merupakan Ibukota Negara. Pada awalnya Lebanon menjadi satu dengan Syiria yang menjadi bagian dari Dinasti Ottoman Turki pada tahun 1516. Sampai selama hampir 400 tahun Dinasti Ottoman Turki masih terus di bawah kekuasaan Islam. Sesudah Perang Dunia I, Lebanon diduduki Inggris dan Perancis. Pada tahun 1920, Liga Bangsa - Bangsa memberikan mandat kepada Perancis untuk memerintah seluruh Syiria, termasuk didalamnya Lebanon. (Harun, 1985: 381). Tahun 1941, Lebanon berhasil memproklamirkan kemerdekaannya dan menjadi suatu negara yang berbentuk Republik. Akan tetapi Perancis baru mengakuinya pada tanggal 27 Desember 1943. Pada bulan Desember 1945 pasukan Perancis baru ditarik dari Lebanon. (Harun, 1985: 381). Identitas politik individu di 
Lebanon banyak ditentukan berdasarkan garis sekte. Bahkan, kesepakatan Thaif 1989, yang menyusun kerangka acuan untuk mengakhiri Perang Saudara yang meletus sejak 1975, mempertahankan distribusi jabatan politik utama bagi kelompok-kelompok agama besar saja. Oleh karena itu, jabatan Presiden masih tetap di tangan Kristen Maronit, Perdana Menteri oleh Muslim Sunni, dan Juru Bicara Parlemen oleh Muslim Syi'i. (Esposito, 2001: 15)

\section{b. Heterogenitas Agama}

Lebanon merupakan satu pemerintahan yang unik karena memiliki banyak agama yang masing-masing mempunyai Sistem Peradilan sendiri dan diakui oleh negara. Tidak ada agama negara. Ada 18 agama atau sekte yang diakui, dua terbesar di antaranya adalah Islam dan Kristen. Penduduk yang beragama Islam mencapai sekitar 59\%, sedangkan Kristen mencapai $40 \%$, yang masing-masing terdiri dari bermacammacam aliran ataupun sekte (https://id.wikipedia.org/wiki/Lebanon).

Islam mayoritas adalah Sunni dan Syi’i (Syi’ah Dua Belas). Pada abad ke11, muncul sebuah agama/aliran baru yaitu komunitas Druze, yang tinggal di wilayah pegunungan bagian Timur dan Selatan Beirut. Minoritas muslim yang lain adalah Syi'ah Alawiyah dan Syi'ah
Ismailiyah.

(http://www.state.gov/g/drl/rls/irf/2002/1 4006.htm).

Sedangkan agama Kristen, mayoritas dipegang oleh Kristen Maronit. Selebihnya adalah Ortodoks Yunani, Kristen Armenia, Melkit, Katholik Suriah, Katholik Roma, Ortodoks Suriah dan Protestan (Ensiklopedi Indonesia: 1990: 158). Pada umumnya orang Kristen memegang posisi penting dalam pemerintahan, termasuk di kalangan militer. Golongan Maronit tidak jarang mempunyai kecenderungan ke arah fasisme dan tidak terlalu memusuhi Israel. Sementara kelompok Islam sebagai mayoritas sering merasa bahwa hak-hak mereka diabaikan hingga mereka menginginkan suatu perombakan politik. Dari segi agama dan budaya, mereka merasa lebih dekat dengan bangsa-bangsa Arab dan mengambil sikap bermusuhan dengan Israel (Harun, 1985: 382).

\section{c. Perang Saudara}

Sebagai sebuah negara yang memiliki penduduk sangat majemuk, tidak heran jika sering terjadi konflik dalam negeri serta pertikaian antar etnis, baik dalam kepentingan politik maupun agama. Selama dibawah kekuasaan Islam, orang-orang Kristen diperlakukan dan di 
beri hak yang sama sebagaimana Muslim. Namun ketika Lebanon di bawah kekuasaan Perancis, golongan Islam sangat dianaktirikan. Oleh karena itu, ketika Lebanon menjadi sebuah negara yang merdeka, golongan Kristen mendominasi segala bidang baik pemerintahan maupun militer (Harun, 1985: 382). Salah satu pemicu terjadinya Perang Saudara yang meletus tahun 1975 adalah ketidaksukaan orang-orang Kristen atas pengungsi Palestina yang jumlahnya semakin bertambah. Semenjak Israel menduduki Palestina 1948, pengungsi dari Palestina terus berdatangan ke Lebanon, mengakibatkan jumlah golongan Islam semakin bertambah baik kualitas maupun kuantitas. Tentu saja golongan Islam menerimanya dengan penuh rasa persaudaraan, karena pada dasarnya, golongan Islam Lebanon merasa bahwa dirinya adalah bagian dari masyarakat Arab yang wajib membela perjuangan Arab termasuk pembebasan Palestina (Harun, 1985: 382).

Pertikaian terus berlanjut hingga meletus perang saudara antara Islam dan Kristen tahun 1975, termasuk keterlibatan Syiria dipihak Kristen, semakin membawa banyak korban dan kerugian di kalangan Islam terutama muslim Palestina. Seperti melengkapi penderitaan umat Islam Lebanon, pada tahun 1982 Israel melakukan invasi militer ke Lebanon secara besar-besaran, baik lewat darat, laut maupun udara. Kondisi inilah yang bertahun-tahun merobek-robek negara Lebanon menjadi puing-puing berserakan hingga tahun 1990.

\section{Perkembangan Sistem Hukum}

\section{Keluarga}

Semenjak tahun 1516 sampai 3-4 abad ke depan, Lebanon berada dibawah perundang-undangan Ottoman Turki Usmani. Undang-undang Sipil Perancis juga membawa banyak pengaruh terhadap perkembangan hukum Lebanon, mengingat Lebanon di bawah jajahan Perancis semenjak tahun 1918 sampai 1943. Namun pengaruh tersebut tidak membawa perubahan substantif pada Ottoman Law of Family Rights 1917. (http://www.law.emory.edu/IFL/legal/leb anon.htm ). Karena mempunyai populasi yang sangat heterogen, maka masingmasing agama mayoritas mempunyai sistem hukum sendiri dan diakui oleh Negara. Hal-hal yang mengatur tentang pengorganisasian sistem hukum tersebut diatur dalam Shari'a Courts Reorganization Law 1942. Berdasarkan peraturan tersebut, dijelaskan bahwa mayoritas muslim Sunni bermazhab Hanafi, dan peraturan yang dipakai adalah Law of Family Rights 1917, 
namun apabila ada hal-hal yang tidak terdapat dalam undang-undang tersebut, dikembalikan kepada pendapat-pendapat dari mazhab Hanafi (Tahir Mahmood, 1972: 35.). Pada tahun 1962, dibentuklah suatu undang-undang yaitu The Law of the Rights of the Family 1962, yang diterapkan oleh kalangan Sunni Hanafian untuk kasus-kasus personal yang tidak tercantum dalam Law of Family Rights 1917 ( http://www.law.emory.edu/IFL/legal/le banon.htm).

Sementara kalangan Syi'ah Isna Ashariyah bermazhab Ja'fari, mereka akan merujuk pada Law of Family Rights 1917 hanya apabila tidak bertentangan dengan peraturan yang digunakannya yaitu Decree Law No. 35031926 (Tahir Mahmood, 1972: 35). Namun apabila ada hal-hal yang tidak tercantum dalam peraturan tersebut, maka dikembalikan kepada pendapat dari mazhab Ja'fari.

Kalangan minoritas Druze justru mempunyai peraturan tersendiri yang sudah diundangkan, yaitu The Duruz Family Law 1948 , sedang Ottoman Law of Family Rights hanya akan digunakan bila ada permasalahan yang penyelesaiannya tidak tercantum dalam Undang-undang mereka (Dawoud El Alami, Doreen Hinchcliffe, 1996: 171180). Keberadaan komunitas Druze di
Lebanon yang merupakan sekte keagamaan minoritas, memiliki posisi yang penting. Karena pada kenyatannya, sepanjang lima belas tahun perang saudara yang mengguncang Lebanon, Druze berhasil menjalin solidaritas yang kuat.

\section{Peraturan Tentang Sistem Wakaf di}

\section{Lebanon}

a. Kodifikasi Peraturan Wakaf

Peraturan-peraturan yang ada dalam Ottoman Family Law hanya meliputi permasalahan-permasalahan seputar pernikahan, perceraian serta persoalan-persoalan lain yang berhubungan dengan kedua hal tersebut. Tentang wasiat, hibah maupun wakaf tidak diatur dalam Undang-undang tersebut. Dalam hal ini jika ada permasalahan seputar hibah, wasiat maupun perwakafan, maka persoalan dikembalikan kepada masing-masing mazhab yang dianutnya.

Dalam perkembangannya, persoalan wakaf semakin komplek dan dirasa perlu untuk membentuk suatu lembaga tersendiri untuk menanganinya. Maka pada tahun 1947, diundangkan The Law of Family Waqf 1947. Materi undang-undang ini banyak mempunyai kemiripan dengan Undang-undang Wakaf Mesir 1946. Undang-undang 
Wakaf Mesir 1946 ini sudah diamandemen 2 kali, pertama, tahun 1952, yang isinya menghapus keseluruhan tentang peraturan wakaf ahli, yang selama bertahun-tahun sebelumnya diperdebatkan. Jadi UU Wakaf 1946 hanya berlaku untuk ketentuan wakaf publik saja. (Norman Anderson, 1976: 168). Pasal-pasal dalam undang-undang banyak mengatur tentang administrasi wakaf, yang antara lain berisi seputar prosedur pembuatan wakaf, pencabutan harta wakaf oleh wakif, wakif mempunyai hak untuk merubah persyaratan-persyaratannya, (Pasal 7 UU Family Wakaf Lebanon 1947), adanya pertukaran yang dilakukan oleh wakif terhadap harta yang diwakafkannya, yang kesemuanya itu dianggap sah bila sudah didaftarkan pada lembaga yang menanganinya. Hal itu diperuntukkan adanya ketegasan secara hukum dalam administrasi perwakafan ( Pasal 7 UU Famili Lebanon 1947).

Dalam kaitannya dengan wakaf ahli (wakaf keluarga), peraturan Lebanon menyatakan bahwa perwakafan harus diakhiri apabila mereka tidak mampu secara ekonomi, atau tidak dapat memperbaiki kerusakan-kerusakan yang terjadi pada harta wakaf, dan apabila ada perluasan atau pertambahan ahli waris (Tahir Mahmood, 1987: 305). Umumnya beberapa negara Muslim menempatkan seorang pengawas dari negara, untuk mengamati perkembangan harta wakaf dalam wakaf ahli.

Dalam pasal 8-10 UU Wakaf Lebanon disebutkan bahwa wakaf yang berupa masjid sifatnya kekal atau untuk selamanya, sedangkan wakaf dalam bentuk benda yang lain, bisa bersifat kekal, bisa bersifat temporer. Dalam hal wakaf keluarga, si penerima atau ahli waris yang menerimanya tidak boleh lebih dari 2 orang tanpa batasan umur. Apabila perwakafan ditujukan untuk maksud-maksud tertentu, di beri batasan waktu yang lamanya tidak boleh lebih dari 60 tahun setelah kematian si wakif. Wakif mempunyai hak penuh untuk menentukan batas waktu berlakunya, atau merubah persyaratanpersyaratannya, bahkan untuk mencabut kembali harta wakafnya. Apabila si wakif ini tidak menggunakan haknya, dan kemudian terjadi penyalahgunaan atau penyimpangan dalam pengelolaannya, maka Undang-undang berhak menyelesaikan sesuai ketentuanketentuan yang telah diterapkan dalam pasal-pasalnya.

Adapun jumlah harta yang boleh diwakafkan adalah maksimal sepertiga dari keseluruhan kekayaan yang dimiliki, dan bisa dilakukan untuk siapa saja (keturunan, pasangan, orang tua) dan bisa mulai dioperasionalkan baik pada 
saat wakif masih hidup maupun sudah mati (Pasal 36-39 UU Wakaf Keluarga Lebanon 1947). Pasal pasal tersebut berisi tentang pemberian wakaf kepada siapa saja baik keturunan, pasangan, orang tua yang sifatnya tidak mengikat. Dalam pasal 10 disebutkan bahwa jika tenggang waktu yang diberikan telah berakhir, maka harta wakaf harus dikembalikan kepada si wakif. Pasal 13 juga menyebutkan bahwa seorang isteri bisa mencabut hak wakaf suami bila dia menceraikannya atau dia menikah lagi dengan wanita lain (Anderson, 1976: 164).

Dengan diundangkannya The Law of Family Waqf tersebut, setidaknya ada perkembangan di bidang pengelolaan wakaf di Lebanon. Meski dalam beberapa kasus wakaf, komunitas non Sunni masih menggunakan pendapat mazhab atau hukum adat yang dianutnya. Druze misalnya, mereka mempunyai sistem perwakafan tersendiri yang dalam beberapa hal berbeda penerapannya dengan wakaf Muslim. Namun adanya konsolidasi yang tinggi di antara mereka, dengan kuantitas yang sangat kecil justru menempatkan mereka pada kesatuan tersendiri yang patut diperhitungkan secara undang-undang.

Ketentuan tentang wakaf keluarga ini masih secara ketat mewarnai sistem perwakafan di Lebanon. Hal ini berbeda dengan negara-negara Muslim lain yang mulai menghapus ketentuan wakaf keluarga (ahli) dan hanya memberlakukan wakaf publik (khairi).

\section{b. Administrasi Wakaf Komunitas Druze \\ Melacak asal usul mereka pada masa sekte Fathimiah di Mesir, Druze merupakan keturunan dari Syiah Ismailiyyah. Setelah lenyapnya Al-} Hakim -penguasa Fathimiyah yang diyakini oleh Druze mempunyai sifat Illahiyah- pada abad ke-11, mereka menemukan tempat pengungsian yang aman di daerah yang kini merupakan wilayah Lebanon,Israel dan Suriah. Kosentrasi terbesar ada di Lebanon, mereka berjumlah sekitar 350.000450.000 jiwa dari keseluruhan penduduk Lebanon yang berjumlah sekitar 4 juta jiwa (Esposito, 2001: 273 dan 379). Meskipun Druze berasal dari Syiah Ismailiyyah, namun mereka telah melepaskan diri dari Islam. Secara teoritis, Druze dapat diterima di Pengadilan Syari'ah dalam perkara perseorangan dan waris, bukan sebagai Muslim, melainkan sebagai orang yang tidak termasuk dalam agama yang diakui (Aharon Layish, 1982: 3). Namun pada saat yang sama, mereka menikmati otonomi dalam perkara tersebut berdasarkan hukum adat dan hukum agama mereka, setelah diundangkannya 
The Druze Family Law 1948. Druze tidak pernah mengajak orang lain untuk memeluk ajarannya, dan keanggotaan mereka dibatasi pada mereka yang lahir dari sekte ini. Oleh karena itu,bahkan dalam satu wilayah yang melakukan endogami (perkawinan satu suku), Druze justru berhasil dalam mempertahankan identitas komunalnya( Esposito, 2001: 273).

Perwakafan pada komunitas Druze mempunyai karateristik sebagai berikut (Aharon Layish, 1990 :129-138).

a. Pewarisan dalam Druze bukan merupakan kewajiban agama,melainkan hanya bersifat anjuran yang disesuaikan dengan tingkat kemampuan secara ekonomi.

b. Sebagian besar harta wakaf dikelola oleh pengelola tersendiri. Pengelola ini bisa dari keluarga tertentu secara turun temurun, atau sesuai dengan perjanjian dalam surat wasiat, atau diangkat oleh para fungsionaris keagamaan atau warga perkampungan setempat.

c. Dalam sebagian besar kasus, pewarisan dibuat untuk tempat ibadah dan tempat-tempat suci lainnya.

d. Pembuat wasiat dapat menunjuk yang menerima wasiat atau anak cucunya untuk membayar jumlah yang diwasiatkannya untuk wakaf setelah kematiannya, dan jika pembayaran tertunda, maka hartanya akan diberikan untuk wakaf.

e. Wakaf kalangan Druze dilakukan dengan jalan wasiat. Para Qadli Druze menegaskan bahwa wasiat merupakan satu-satunya arti bagi pembuatan wakaf. Mereka memperlakukan wasiat seperti waqfiyya ( kharajul wasiyya makhrajul waqfiyya). Meskipun sifat harta wakaf ini tidak ditentukan, namun yang sering terjadi adalah berupa uang untuk diwakafkan atau diwasiatkan. Jarang terjadi harta wakaf berupa barang tak bergerak. Kadang-kadang harta wakaf tidak dipisahkan dengan harta pribadi. Hal ini terjadi karena seseorang tidak menyerahkan seluruh hartanya, tetapi membaginya dengan para ahli waris keluarganya. Pengelola wakaf Druze dikenal dengan berbagai nama seperti wali, mutawalli, qayyim,dan mustasallim al-waqf. Fungsi pengelola ini pada dasarnya tidak berbeda dengan mutawalli dalam wakaf Islam. Pengelola diberi kekuasaan penuh untuk melakukan tindakan apapun dalam hal wakaf, termasuk pembelian, penjualan, peminjaman keluar, penggantian harta wakaf, perbaikan dan pembangunan konstruksi di atasnya dengan ketentuan bahwa semua tindakan itu 
untuk kepentingan maslahah wakaf serta disetujui oleh pengadilan. Komunitas Druze membedakan antara pengelola wakaf pribadi (khususi) dan wakaf komunal (umumi) Wakaf Pribadi berhubungan dengan individu individu, keluarga dan lingkungan tempat tinggal. Wakaf semacam ini biasanya diberikan untuk khalwa (semacam tempat suci atau tempat ibadah yang diagungkan oleh kalangan Druze). Sedang pengelolaannnya dibawah pengelola tunggal. Wakaf komunal berkaitan dengan harta untuk kepentingan negara. Wakaf ini dikelola langsung oleh pimpinan komunitas Druze dan fungsinya turun temurun (Aharon Layish, 1990 :133).

Dengan ketentuan dalam wasiat, pembuat wakaf dapat memberikan hak untuk menjual harta yang telah ia wariskan apabila ternyata kondisi ekonomi menjadi sulit. Penjualan kadang dilakukan oleh wakil dibawah kuasa pengacara yang tidak dapat dibatalkan di luar kantor pendaftaran. Penggantian satu harta wakaf dengan yang lain, juga terjadi di kalangan Druze. Terdapat beberapa kejadian dimana harta wakaf dijual untuk membiayai akuisisi properti, yang berguna bagi khalwa dan untuk komunitas Druze pada umumnya.
(Aharon Layish, 1990 :147).

Perwakafan Druze merupakan proto wakaf yang berakar pada adat dan hukum keagamaan. Harta wakaf Druze sangat sederhana baik dari segi kuantitas maupun kuantitas jika dibanding wakaf Muslim. Wakaf Druze, kurang memberikan sumbangan secara ekonomi terhadap sistem dalam masyarakat seperti pendidikan, kesehatan dan kesejahteraan. Hal ini disebabkan wakaf Druze tidak dikelola oleh lemabaga sentral yang dapat mengarahkan pendapatan dan hasil penjualan harta wakaf ke dalam saluran-saluran yang diinginkan. Namun dia sisi lain sebagai kelebihannya, bahwa putusan wakaf yang dibuat oleh qadli Druze maupun peraturan-peraturan yang berkembang akan menjadi terumuskan. Untuk melakukannya, referensi yang terinspirasi oleh hukum agama, adat lokal, syari'at Muslim, dan undangundang sekuler dibuat menjadi normanorma jurisdiksi religius yang akan memberikan sumbangan yang meyakinkan untuk pelestarian status quo dalam pelestarian wakaf komunitas Druze di Lebanon.

\section{SIMPULAN}

Latar belakang sekte dan agama yang beragam, memungkinkan terjadinya konflik termasuk konflik perwakafan. 
Kondisi ini tentu tidak dapat dihindari mengingat aspek sosiologis yang masing-masing menuntut keadilan individu dan kepastian hukum. Diterapkannya Undang-undang Wakaf Keluarga 1947 di Lebanon, lebih mencerminkan bahwa Lebanon sebagai negara kecil yang sangat heterogen dan bisa dikatakan tidak stabil secara politik, mampu mewujudkan langkah positif untuk mengatasi problema perwakafan.

Meskipun demikian, negara memberi wewenang penuh bagi sekte/agama lain yang mempunyai peraturan sendiri tentang perwakafan. Sebagai contoh Druze, yang meskipun peraturannya tidak terkodifikasi, tetapi punya kekuatan yang mengikat di dalam komunitasnya. Kemungkinan dalam hal ini kelompok Syi'ah, yang dalam penyelesaian masalah perwakafan diselesaikan menurut mazhab yang dianutnya, atau jika tidak ada ketentuan yang mengatur bisa merujuk pada UU Wakaf 1947. Demikian juga untuk sekte-sekte (Islam) kecil yang lain.

Toleransi keberagamaan yang begitu tinggi diberlakukan secara resmi oleh negara, kadang membawa ke arah ketidakpastian hukum. Hal ini tidak bisa dipungkiri, karena universalitas hukum (termasuk masalah perwakafan), tidak akan bisa mengakomodasi keberagaman masalah secara konkrit. Pada akhirnya, langkah Pemerintah untuk "memayungi" berbagai konsep hukum yang berlaku pada tiap agama, adalah yang paling tepat untuk diterapkan, setidaknya sampai saat ini.

\section{DAFTAR PUSTAKA}

Anderson, Norman . 1976. Law Reform in The Muslim World, . London: The Athlone Press.

Esposito, John L. 2001. Ensiklopedi Oxford Dunia Islam Modern, jilid 3, terj. Eva YN dkk, Bandung: Mizan.

Ensiklopedi Indonesia seri Geografi. 1990. Jakarta: PT.Ichtiar Baru van Hoeve.

El Alami, Dawoud dan Hinchcliffe, Doreen. 1996. Islamic Marriage and Divorce Laws of the Arab World, London: Cimel and Kluwer Law International.

Harun, Lukman. 1985. Potret Dunia Islam, Jakarta: Pustaka Panjimas.

Layish, Aharon. 1982. Marriage, Divorce and Succession in the Druze Family, Leiden: E.J.Brill.

Lexicon Universal Encyclopedia. tt. New York : Lexicon Publications, Inc.

Lewis, B., Pellat, CH., Schacht, J., (ed). 1986. The Encyclopedia of Islam, Vol. V. Leiden: E.J. Brill.

Mahmood, Tahir. 1972. Family Law Reform in The Muslim World. Bombay: N.M.Tripathi PVT.Ltd. 1987. Personal Law in Islamic Countries, (History, Text and Comparative Analysis), New Delhi: Academi of Law and Religion.

Ash-Shan'aniy, Muhammad Ibn Ismail. 
Humanika, Vol. 16, Nomor 1, September 2016

t.t. Subulus Salam, juz 3, Mesir: Muhammad Ali Shabih.

http://www.state.gov/g/drl/rls/irf/2002/14 006.htm

http://www.law.emory.edu/IFL/legal/leba non.htm

https://id.wikipedia.org/wiki/Lebanon. 
Humanika, Vol. 16, Nomor 1, September 2016 